\title{
Historical Institutionalism and the European Union's post-Cold War Foreign Policy Development
}

Marek Neuman, University of Groningen, Groningen, the Netherlands

Correspondence: m.neuman@rug.nl

\begin{abstract}
This paper maintains that Historical Institutionalism - with its emphasis on such concepts as path dependency, time, continuity and change, critical junctures, and unintended consequences - serves as a valuable theoretical tool in explaining the why and how of the European Union developing from a strictly economic union during the first forty years of its existence towards a political union with a global foreign policy agenda in the post-Cold War period. Discussing the EU's post-1989 foreign policy development and zooming in on the EU's policy towards Eastern Europe to illustrate its argument, the paper argues that Brussels' participation in global politics has for long been in the making. More specifically, four elements that have determined - and continue to do so - the EU's foreign policy portfolio are first, the successful economic integration in the first forty years of the European Union's existence; second, the logic of integration through institutionalization driving EU integration since 1952; third, the - at first - informal European Political Cooperation witnessing the emergence of tacit norms and rules of conducting foreign policy coordination; and fourth, the rhetoric commitment to the region of Central and Eastern Europe pre-1989.
\end{abstract}

\section{KEYWORDS:}

European Union, foreign policy, Historical Institutionalism, path dependency, unintended consequences, European Neighbourhood Policy, Eastern Partnership 


\section{Introduction}

The eve of the thirtieth anniversary of the dissolution of the Soviet Union - and the accompanying bipolar nature of the international arena - provides good grounds for assessing how new actors developed their foreign and security policy agendas to occupy a spot in the new multipolar global order. Whereas in doing so, much scholarly attention has been paid to the rise of the so-called BRICS countries (Brazil, Russia, India, China, and South Africa), ${ }^{1}$ the European Union (EU) - somewhat surprisingly at first sight, - also made its entry to the world of global high politics. Surprising because the European Union, when established, was anything but a foreign policy actor. Set up as an economic entity among six Western European countries in the early 1950s, its main goal was the establishment of a common market to facilitate free movement of goods, services, capital and workers. Throughout the first forty years of its existence, then, we observe much institutional and policy development geared towards achieving this fundamental goal of establishing the - by now dubbed - single European market. While the development of a proper single European market necessitated the development of a (limited) external dimension - whether in the shape of establishing a common external tariff for non-EU imports or negotiating EU-wide trade agreements with third countries - the European Union's foreign policy profile remained a low one. Yet, assessing the very same Union today, one cannot but notice that it has developed into an actor that, rather than shying away from getting involved in global politics, aims at taking center stage; whether as an observer to the United Nations, a peacekeeper in Ukraine, or a party to the Iranian Nuclear Deal, to name only a few. ${ }^{2}$

The present paper discusses the development of the European Union as a foreign policy actor in the post-Cold War era. It does so by adopting a historical institutionalist (HI) approach, rather than looking for explanations within the more traditional approaches to understanding international relations; whether realism, liberalism, or social constructivism. ${ }^{3}$ Consequently, this paper maintains that the European Union's venturing into high global politics may be less surprising than initially might appear. The rapid institutional development within the area of the EU's global agency that we observe over the past thirty years should be understood as a result of internal and external developments. Whereas the former mainly centers around the $\mathrm{HI}$ concept of path dependency, the latter predominantly refers to global events unleashed with the end of the Cold War and the subsequent demise of the Soviet Union in 1991. Similarly to M. Vachudova, who in her analysis of the EU's enlargement argued that the way EU expansion would ultimately turn out was shaped "[w]ell before the collapse of the Soviet bloc in 1989,"4 this paper maintains that the Union's foreign policy development and agenda post-Cold War has been long in the making.

Yet, while being thrust into the newly developing multipolarity in the aftermath of the Cold War as a result of the abovementioned combination of internal and external pressures, the European Union's ability to develop effective agency has been severely limited due to its inherently complex institutional structure. Having to maneuver

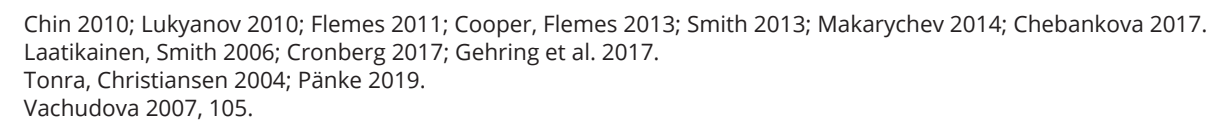


between intergovernmentalism on the one and supranationalism on the other end with the scale prominently tilting towards the first within the domain of foreign policy, - its global ambitions are often greater than the accompanying instruments it has at its disposal. ${ }^{1}$ Nowhere is this more visible than in the EU's development of a foreign policy approach towards Eastern Europe, whether in the shape of the European Neighbourhood Policy (ENP) or the more recent Eastern Partnership (EaP). At the same time, however, this paper argues that not developing a policy framework vis-à-vis Eastern Europe was not a viable option for the European Union either, leaving Brussels in a difficult and vulnerable position.

To answer this paper's main question - namely whether and how Historical Institutionalism helps us to understand the development of the European Union's foreign policy agenda in the post-Cold War period - the remainder of this article is structured as follows. After this short introduction, the theoretical and methodological considerations underpinning this research are explained, with the main focus lying on the applicability of Historical Institutionalism to the study of EU (foreign) policy development. This is followed by a discussion of the EU's development as a foreign policy actor post-Cold War from a HI perspective. Paying attention to concepts such as path dependency, time, continuity and change, critical junctures, and unintended consequences, the section argues that $\mathrm{HI}$ sheds light on why (and how) the Union abandoned the idea of being an economic union in favor of developing a political dimension as well. Subsequently, the paper zooms in on the EU's foreign policy towards Eastern Europe, providing a snapshot of the argument made throughout the paper. The concluding section summarizes the main findings.

\section{Institutions Matter: Historical Institutionalism and Methodological Considerations}

With other new institutionalist variants - particularly Rational Choice, Sociological, and Discursive Institutionalism² - Historical Institutionalism shares the fundamental premise that "institutions matter." 3 Similarly, all these variants share a definition of institutions, which are seen as both formal and informal rules and norms that depending on the strand in question - determine an actor's behavior and/or identity. ${ }^{4}$ HI's specific contribution to the growing body of scholarly literature theorizing European integration lies in its focus on the effects institutions have on actor behavior over a longer period of time; put simply, "history matters, too." As P. Pierson first summarized it, Historical Institutionalism is "[h]istorical because it recognizes that political development must be understood as a process that unfolds over time. It is institutionalist because it stresses that many of the contemporary implications of these temporal processes are embedded in institutions - whether these be formal rules, policy structures, or norms."5

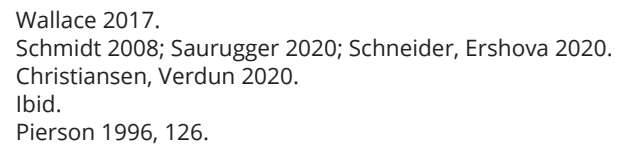


Consequently, early $\mathrm{HI}$ scholarship of the European integration process focused on explaining continuity, by arguing that actors' decision- and policy-making is largely constrained by decisions taken - and policies created - in the past. Such path dependency, or being "locked in" in certain policy alternatives, largely explains why EU institutions - rules, policy structures, or norms - tend to persist over time. ${ }^{1}$ At the same time, $\mathrm{HI}$ scholars were faced with the fact that despite the overwhelming tendency of EU institutions to persist, change does occur, too. Hence, institutional change was conceptualized as occurring as a result of so-called critical junctures, defined as "relatively short periods of time during which there is a substantially heightened probability that agents' choices will affect the outcome of interest."2 First viewed as a result of sudden, exogenous shocks, but in more recent literature also as a result of incremental, endogenous forces, a window of opportunity for substantial change in the course of action opens. ${ }^{3}$ If taken advantage of, path dependency can be mitigated against, if not, the window of opportunity closes and the initial institution has once again persisted.

With its longue durée approach to European integration, its emphasis on institutional continuity and change, and its ability to problematize critical junctures, Historical Institutionalism has established itself firmly among the theories of European integration. Not only has it been applied to studies of the European integration process writ large and of individual EU institutions, but it has also been increasingly applied to make sense of developments within various EU policy areas. Most commonly, we find $\mathrm{HI}$ explanations of EU social, market, and monetary policies, ${ }^{4}$ but also the EU's external relations dimension has not remained untouched. As such, M. Vachudova discusses the EU's enlargement policy as a case in point supporting the HI hypothesis of earlier designed policies determining the course of action with regard to the European Union's external agenda. In her work, she highlights the centrality of unintended consequences resulting from institutions created in a given spatio-temporal context; the European Union's enlargement to Eastern Europe, itself a result of Western Europe's successful economic integration pre-1989, has led to the enlargement agenda de facto becoming a democratization agenda, but also to the development of enlargement fatigue making any further enlargement less likely and more complex. ${ }^{5}$

Yet, with the notable exception of Ginsberg and Smith, ${ }^{6}$ little historical institutionalist research has been conducted into the European Union's development as a foreign policy actor, beyond enlargement policy. ${ }^{7}$ Building upon Ginsberg and Smith's argument that, defying the many sceptics, the "EU [...] grew into a true global political actor rather than remaining a regional economic power," ${ }^{\prime 8}$ this paper attempts to remedy for the relative absence of $\mathrm{HI}$ theorizing in the area of EU foreign policy. It does so by zooming in on the area of EU foreign policy vis-à-vis Eastern Europe first in the shape of the European Neighbourhood Policy and later in the form of

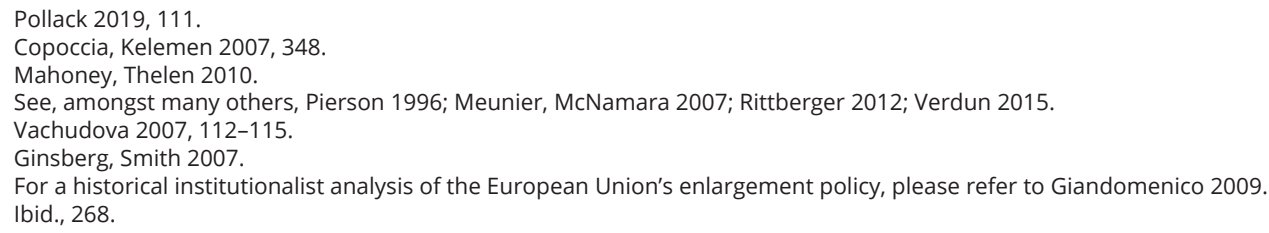


the Eastern Partnership - making use of the above-discussed theoretical concepts of path dependence, time, continuity and change, critical junctures, and unintended consequences. The paper relies on desk research, analyzing both relevant primary and secondary literature; whereas the first refers to EU treaties and documents that are pertinent to our understanding of the EU's foreign policy development and agenda post-Cold War, the second refers to the growing body of scholarly literature on the very same topic.

\section{From Economic to Political Union: The Role of Institutions and Exogenous Shocks}

Against the backdrop of a failed integration attempt in the area of defense - and foreign - policy in the early 1950's that would have assumed the form of a European Defense Cooperation, six Western European countries - Belgium, France, Italy, Luxembourg, the Netherlands, and the Federal Republic of Germany - embarked upon the path of integrating the (West) European continent in economic terms. From a neo-functionalist logic, for which the concept of functional spillover is central, ${ }^{1}$ the six European countries had spent the first four decades of the European integration process creating an economic union, which would see the European Communities as the EU was known back then - establish itself as a zone of prosperity, economic growth, and innovation. What began with the creation of the European Coal and Steel Community (ECSC) in 1952, gained in traction with the signing of the Treaty of Rome in 1957, launching the European Economic Community (EEC). In the period 1952 to 1992, the bulk of European integrationist activity was geared towards solidifying the single European market in order to fully achieve the four fundamental freedoms proclaimed in Rome; free movement of goods, services, capital and workers. ${ }^{2}$ As such, we see the gradual addition and institutionalization of new policy areas that are being considered instrumental to a European single market, whether in the area of, for instance, agriculture, competition, customs, fisheries, or transport. Accompanying the widening portfolio of EU policy areas is a steady, but certainly not linear, communitarization - or supranationalization - of EU policy- and decisionmaking. Both the expansion of policy areas and the supranationalization of the European Union - mostly taking the form of policy proposals being put forward by the European Commission rather than individual member states and of decisions being taken by qualified majority voting (QMV) rather than unanimity - defined particularly the 1980s. The Single European Act (SEA), signed in 1986, then codified both these trends, next to setting out the EU's agenda for the years to come; in line with its economic character, the European Union was to focus on establishing a monetary union among its member states, thereby eliminating one of the most visible obstacles to a well-functioning single European market. ${ }^{3}$

2 European Economic Community, "Vertrag zur Gründung der Europäischen Wirtschafsgemeinschaft (Treaty Establishing the European Economic Community)," Eur-Lex, accessed March 18, 2021, https://www.eur-lex.europa.eu/legal-content/DE/TXT/ PDF/?uri=CELEX:11957E/TXT\&from=EN. Please note that the original text of the Treaty of Rome is only available in Dutch, French, German, and Italian; the official languages of the six EEC founding members.

3 European Communities, "Single European Act," Official Journal of the European Communities, accessed March 18, 2021, https:// www.eur-lex.europa.eu/legal-content/EN/TXT/PDF/?uri=CELEX:11986U/TXT\&from=EN. 
Only very few exceptions to this purely economic logic behind European integration marked the first four decades of European integration. Amongst the most visible ones is the European Union's willingness to enlarge; whereas in 1957, the EU counted six member states, it boasted 12 members by the time of signing the SEA. ${ }^{1}$ While Cold Wardriven geopolitical considerations most certainly also played a role in explaining both the desire to join the European Union and the EU's willingness to absorb more states, the enlargement process itself was primarily driven by an economic integrationist logic; it centered around access to the EU's internal market and economic assistance. ${ }^{2}$ Next to the EU's enlargement portfolio, voices for the European Union going beyond a purely economic union began to be increasingly heard in the late 1980s; as a result of the accelerated single European market program, some began to argue for the need to accompany the economic character of the union with a social policy. Once again, from an economic point of view, if full free movement of goods, services, capital, and workers was to be achieved, this would necessitate some level of harmonization in the areas of, among many others, pension, health care, and diploma/training recognition.

Of particular importance to this paper, though, is the informal (at first) development of foreign policy cooperation among the then EU member states that took the form of the European Political Cooperation (EPC) and that took shape in parallel to the formal economic integration of the European Union. Emerging from the 1970 Davignon report, the EPC set out to improve the mutual understanding of foreign policy preferences among the six EU member states, to enable a political dialogue on foreign policy matters, and to strengthen solidarity among participating countries. Where attainable, the EPC was also to enable mutual decisions. ${ }^{3}$ Intergovernmental in nature, the EPC at first remained fully isolated from the institutionalized economic integration among Western European countries; informal meetings among participating ministers of foreign affairs took place biannually (later four times a year) and primarily served as a forum for consultation on a limited range of topics, with issues such as security or post-colonial relations remaining off limits. It was not until the Single European Act that the EPC was integrated into the European Union's institutional structure with a small permanent secretariat established in Brussels. And yet, despite its initially informal, under-institutionalized, and non-funded character, the sole habit of discussing foreign policy matters gave rise to norms that continue to inform the European Union's foreign policy until today; the principles of "confidentiality, consensus, and consultation." ${ }^{4}$ As de G. Bassompierre put it, what emerged among the EU member states as a result of foreign policy socialization was a "consultation reflex" that saw no member state "willing to jeopardize present commitments to consult before adopting formal positions or launching national initiatives on important international questions of mutual concern." ${ }^{5}$ This paper argues that these implicitly accepted norms guiding early EU foreign policy consultations - in conjunction with the successful economic integration among Western European countries and with the European Union's “integration by institutionalization"

\footnotetext{
The new members were: Denmark, Ireland, and the United Kingdom (1973), Greece (1981) and Portugal and Spain (1985).

2 In contrast to later enlargement rounds that would follow in the 2000s, the EU did not design an explicit democratization, and rule of law-based trajectory that candidate countries had to successfully implement to qualify for enlargement.

Keukeleire, Delreux 2014, 42-46.

Smith 2001, 87.

Bassompierre 1988, 49.
} 
logic - laid the groundwork for the rapid development in EU foreign policy making in the post-Cold War period.

Throughout the 1980s, the EPC/EU developed an agenda supporting structural change in third countries/regions, targeting primarily Central and Eastern European countries and their attempts at reforming their socialist regimes. ${ }^{1}$ However, the loosely institutionalized and poorly staffed EPC structures soon proved insufficient to adequately respond to a series of exogenous shocks occurring at the fringes of the European Union in the late 1980s and early 1990s, potentially compromising the EU's stability and prosperity. Particularly the end of the Cold War with the subsequent dissolution of the Soviet Union, the ensuing emergence of newly independent and newly sovereign countries at the European Union's Eastern border, and the violent dissolution of Yugoslavia proved to be a critical juncture in the development of the EU's foreign policy domain. A window of opportunity for those member states wishing to turn the European Union from a purely economic to a political union opened up, and was adequately instrumentalized by means of calling for a second intergovernmental conference to complement one planned earlier to discuss monetary integration, both to take place in Maastricht in early 1992.

As a result of several institutions called into life throughout the first forty years of the EU's existence, and thus in line with HI's emphasis on path dependency, the Treaty on European Union signed in Maastricht established the European Union's Common Foreign and Security Policy (CFSP), a highly institutionalized and formalized set-up to enable the European Union's participation in global affairs. Particularly the following norms have driven the EU's post-Cold War foreign policy development: first, the historical insistence of being a value-based community open to "any European State," 2 second, its long-established integrationist logic designed to overcome European crises by accelerating and deepening integration, and third, its widely-accepted notion of consensus/intergovernmentalism in the domain of foreign policy coordination paired with a coordination reflex. Founding the CFSP, intergovernmental in character and equipped with explicit instruments (common actions and common positions), can thus be seen as the European Union's response to the emerging multipolarity in the aftermath of the Cold War.

While boasting global ambitions, the development of an EU foreign policy agenda was first and foremost driven by the need to address the impending question of EU enlargement to the East. Not only was further EU enlargement a result of forty years of successful economic integration in Western Europe, as M. Vachudova maintains, ${ }^{3}$ but it was also an outcome of the EU's normative commitment towards the region in the past. Having rhetorically encouraged democratic reform throughout the Cold War, it came as little surprise that the newly independent and newly sovereign countries of Central and Eastern Europe turned to Brussels for assistance/guidance in regard to their transition towards liberal democracies with a capitalist market economy. ${ }^{4}$ However, this paper goes beyond the argument that EU expansion to the East has

2 European Communities, "Treaty on European Union," Official Journal of the European.Communities, p. 63, accessed March 22, 2021, https://eur-lex.europa.eu/legal-content/EN/TXT/PDF/?uri=CELEX:11992M/TXT\&from=EN. 
been determined before the collapse of the Soviet Union, by maintaining that the first forty years of Western Europe's (economic) integration lay the groundwork for foreign policy development post-1983 writ large.

To an extent, then, the EU has been thrust into global politics in the late 1980s/early 1990 s as a result of a combination of endogenous shocks and an internally-constructed logic of ever-progressing integration and expansion. If economic integration proved to be the rationale behind cooperation among Western European countries post-WWII, foreign policy development was to shape European integration post-Cold War. This is attested by the quick sequence of reform treaties that saw the light post-1989 and that often centered around the enlargement/foreign policy domains. The Treaty of Amsterdam (1999) created the function of High Representative of the CFSP, thereby creating the position of a permanent foreign policy official that would represent the European Union towards the outside world, next to establishing the instrument of "common strategies," which was to enable longer-term, strategic planning vis-à-vis third countries and regions. ${ }^{1}$ The Treaty of Nice (2001) predominantly focused on internal institutional reforms that were to prepare EU structures for the impending enlargement, but also contained foreign policy provisions, such as the possibility to nominate EU special representatives. ${ }^{2}$ The most visible institutional development in the area of foreign policy, though, came with the Lisbon Treaty (2007). Not only has the position of the High Representative of the CFSP (as of now dubbed High Representative for Foreign Affairs and Security Politics) been linked to the post of vice-president of the supranational European Commission (thereby creating an explicit link between the supranational and intergovernmental elements of European integration), but the Treaty also established the European Union's diplomatic service, the European External Action Service (EEAS). ${ }^{3}$ Yet, despite all these developments over the last thirty years, the foreign policy cooperation norms as established pre-1989 - particularly the principle of consensus - proved to be resilient to change and continue to dictate EU foreign policy up until the present day.

In parallel with institutionalizing its foreign policy presence, the European Union built its foreign policy agenda. Centered around questions of enlargement and development aid to the countries of the Global South (often former colonies of individual member states) in the 1990s, its agenda grew to encompass virtually all regions in the world and a broad range of policy matters, from multilateralism, over human rights and climate change, to terrorism and the proliferation of weapons of mass destruction. The European Union's response to these challenges was summarized in its first ever foreign policy strategy in 2003, which clearly marked the EU's arrival on the stage of global politics. Entitled "European Security Strategy: a Secure Europe in a Better World," the Union's foreign policy conception was still largely driven by the enlargement logic in that it put much emphasis on regime transformation and

1 European Union, "Treaty of Amsterdam," Official Journal of the European Communities, accessed March 22, 2021, https://eur-lex. europa.eu/legal-content/EN/TXT/PDF/?uri+CELEX:1997D/TXT\&from=EN.

2 European Union, "Treaty of Nice," Official Journal of the European Communities, accessed March 24, 2021, https://eur-lex.europa. eu/legal-content/EN/TXT/PDF/?uri=CELEX:12001C/TXT\&from=EN.

3 European Union, "Treaty of Lisbon," Official Journal of the European Union, accessed March 24, 2021, https://eur-lex.europea.eu/ legal-content/EN/TXT/PDF/?uri=OJ:C:2007:306:FULL\&from=EN. 
the promotion of democracy, human rights and the rule of law. ${ }^{1}$ Yet, without the accompanying foreign policy tools and transformation incentives, the EU's strategy proved to be too ambitious, suffering from a rhetoric-practice gap; on paper, the European Union had outlined a determined, normative agenda, but on the ground, it had to concede much of its goals as a result of not being sufficiently equipped and often not speaking with one voice. ${ }^{2}$ Consequently, the EU's second foreign policy strategy, published in 2016 and entitled "A Global Strategy for the European Union's Foreign and Security Policy," argued for the EU's foreign policy being guided by "principled pragmatism;" not compromising on its own values, the European Union needs to pursue its interests in a manner taking into account its own strengths. ${ }^{3}$ The strategy thereby also implicitly acknowledged the Union's (institutional) weaknesses, calling for the strengthening of global multilateralism as a way to remedy for these. Differently from earlier on, emphasis was no longer put on promoting democratic change abroad, but rather on strengthening resilience in its near and more distant neighbourhood. ${ }^{4}$

\section{The European Union's Foreign Policy vis-à-vis Eastern Europe: Surpringly Unexpected}

The final section of this paper introduces a discussion of the European Union's foreign policy towards Eastern Europe in a bid to support the previously elaborated argument, namely that the EU's institutional and in-scope development in the area of foreign policy can be understood from a historical institutionalist perspective by placing emphasis on, among others, EU norms and policies established during the first forty years of EU integration, as these continue to drive foreign policy development today. More specifically, it builds upon M. Vachudova's argument that the EU's enlargement policy that emerged as a central feature of its foreign policy post-1989 was determined long before the end of the Cold War, by arguing that so was the Union's outreach to the region of Eastern Europe. The substance of the argument is simple: the European Union's focus on bringing Central and Eastern European countries into the European Union throughout the 1990s and early 2000s has made Brussels' involvement further East, to a large extent, inevitable. And while any EU foreign policy vis-à-vis such countries as Armenia, Azerbaijan, Belarus, Georgia, Moldova, and Ukraine was implausible pre1989, its contours began to be drawn then, being continuously refined with every enlargement-related decision taken post-1989.

With the EU enlargement process comprising twelve - mostly Central and Eastern European ${ }^{5}$ - countries coming to an end with the signing and ratification of the Treaty of Accession in 2003 and 2005, the European Union's new, Eastern, neighbourhood quickly came into focus. This was not only a result of the EU's drive to stabilize and securitize its neighbourhood - much in line with the logic driving the EU's enlargement

1 Council of the European Union, "European Security Strategy: A Secure Europe in a Better World," accessed March 22, 2021, https://data.consilium.europa.eu/doc/documents/ST-15895-2003-INIT/en/pdf.

2 Tocci 2009.

3 European External Action Service, "A Global Strategy for the European Union's Foreign and Security Policy: Shared Vision, Common Action: A Stronger Europe," accessed March 23, 2021, https://eeas.europa.eu/sites/default/files/eugs_review_web_0.pdf.

4 Juncos 2017; Tocci 2020.

5 Of the twelve countries that eventually joined the European Union in 2004 and 2007, ten were Central and Eastern European ones; the Czech Republic, Estonia, Latvia, Lithuania, Hungary, Poland, Slovenia, and Slovakia joined in 2004, with Bulgaria and Romania following in 2007. The remaining two countries to join were Cyprus and Malta. 
policy a decade earlier, - but also a result of the new EU member states wanting to put their recently gained transition experience to use. Unwilling and unable to provide any of the new neighbouring countries with an EU membership perspective, in itself problematized as one of the unintended consequences of the EU's Eastward enlargement, ${ }^{1}$ the European Union continued following the logic of institutionalization, establishing the European Neighbourhood Policy (ENP) in 2003. Largely based upon the European Union's market attraction - built upon economic association through free trade agreements, - the ENP is not only meant to bring Eastern European countries closer to the EU, but also addresses the Southern European (Mediterranean) border countries. ${ }^{2}$ Yet, ever since its inception, the ENP framework has suffered from many shortcomings that inhibit its transformational potential vis-à-vis its partner countries. As such, the ENP has been criticized for its emphasis on bilateralism, rather than trying to bring the region(s) together in an effort to solve the many outstanding issues amongst which first and foremost the many (frozen) conflicts - multilaterally. ${ }^{3}$ It has been criticized for being under-funded, resulting in having only very limited, if any at all, impact on third state transformation. ${ }^{4}$ It has been problematized as suffering from the European Union's dividedness on many foreign (but also economic) policy issues, and for not defining clear benchmarks against which any possible progress - followed by closer association - can be objectively measured. ${ }^{5}$ Most relevant to this paper are two policy decisions that have - in true historical institutionalist fashion - driven ENP reform and development in later years. First, the non-inclusion of the largest of the Eastern European countries and simultaneously the most important EU economic partner in the region, the Russian Federation, in the ENP framework. ${ }^{6}$ While not by choice, but rather upon Moscow's own insistence on developing a separate framework for structuring EU-Russia relations, ${ }^{7}$ Russia's non-presence in the ENP severely inhibited the EU's policy framework ever since its launch, seeing both Russia's ties and ambitions in the region now constituting the "shared neighbourhood." Second, the grouping together of countries of both the Mediterranean basin and Eastern Europe in one policy framework; countries that not only perform very differently along most indicators (be it political regime, civil society participation, economic development, and others), but that also harbor very distinct ambitions vis-à-vis the European Union itself. Whereas the countries of the Mediterranean basin do not express any intention to become part of the Union, some countries of Eastern Europe - such as Georgia, Moldova, or Ukraine - have openly underlined their ambitions to join the EU in the medium- to long-term. It is the European Union's unwillingness to answer these calls for a membership perspective that is often presented as yet another inherent weakness of the ENP. ${ }^{8}$

\footnotetext{
Vachudova 2007, 115-118

2 The Mediterranean countries grouped under the European Neighbourhood Policy are Algeria, Israel and the Palestinian Authority, Egypt, Jordan, Lebanon, Libya, Morocco, Tunisia, and Syria.

Sasse 2009.

Missiroli 2010.

Smith 2005.

Comelli 2004

7 EU-Russia relations have, since the 2003 Saint-Petersburg EU-Russia Summit, been structured in the so-called "Four Common Spaces" framework; a Common Economic Space, a Common Space of Freedom, Security and Justice, a Common Space of External Security, and a Common Space of Research and Education.

8 Sasse 2008.
} 
Some of these challenges to the European Neighbourhood Policy were addressed by the creation of two region-specific sub-frameworks; the Union for the Mediterranean (2008) and the Eastern Partnership (2009), of which particularly the second is of interest to this section. ${ }^{1}$ Both the emergence and the structure of the EaP can be assessed through the historical institutionalist lens; its launch has been accelerated in the aftermath of the Russo-Georgian war of August 2008, which can be seen as a critical juncture in the ENP's development, opening a window of opportunity for EU member states with a foreign policy interest (and expertise) in Eastern Europe to push for more robust engagement with countries of the region. ${ }^{2}$ The ensuing Eastern Partnership, then, is an example of both continuity and change of the earlier ENP; whereas the EaP continues to rely on the long-established integrationist logic and on the EU's economic appeal (manifested in the Deep and Comprehensive Free Trade Agreements to be concluded with the individual partner countries), we also see the addition of new policy portfolia structuring EU-EaP relations. As such, besides focusing on the economy and market harmonization, cooperation spans the areas of good governance, connectivity, and strengthening civil society, for which the Civil Society Forum has been launched in parallel to the EaP itself. While the Eastern Partnership, compared to the ENP, expanded the EU's outreach, this still takes place within a broad framework defined by the absence of a tangible EU membership perspective for the EaP countries in question.

Historical Institutionalism seems to hold great explanatory power when assessing not only why, but also how, the European Union developed a foreign policy agenda towards the neighbourhood at large, and the Eastern European neighbourhood more specifically. Furthermore, a historical institutionalist reading of the ENP and EaP also directs our attention to the so-called unintended consequences of decisions made and policies created in the past. With regard to the ever-enhancing EU involvement in Eastern Europe, the one unintended consequence most certainly is the heightened tensions in the European Union's relationship with the Russian Federation. While extending beyond the scope of this article, the deterioration of EU-Russian relations as a result of, first, the European Union's enlargement to the East and, second, the Union's foreign policy agenda vis-à-vis Eastern Europe, at times seen as Russia's own sphere of influence, have sparked much scholarly attention. ${ }^{3}$ Yet, with the notable exception of T. Casier's work, this scholarly focus only rarely conceptualizes the quality of EU-Russian relations as an unintended consequence of policy decisions made in a different spatio-temporal context. ${ }^{4}$

\section{Conclusion}

This paper attempted to shed light on the European Union's rapid transformation from a strictly economic entity spanning several Western European countries during the Cold War

1 The Eastern Partnership comprises all the EU member states and the six Eastern European countries of the ENP, namely Armenia, Azerbaijan, Belarus, Georgia, Moldova and Ukraine.

2 Neuman 2015, 95-142.

3 Averre 2009; Trenin 2009; Dias 2013; Cadier 2014; Bechev 2015; Delcour 2015; Kazharski and Makarychev 2015; Delcour 2018; Noutcheva 2018.

4 Casier 2019. 
into a political union of - currently - twenty-seven member states, boasting a vibrant foreign policy agenda active in global politics. In assessing why and how the European Union, post1989 , became one of the poles in the newly multipolar global order, this paper introduces a historical institutionalist reading of the Union's (foreign) policy development to supplement the many existing - more traditional - approaches to the study of European integration. As such, this paper should not be read as substituting for these alternative theoretical explanations, but rather as complementing these by elaborating upon the contribution that Historical Institutionalism can make in furthering our understanding of the European Union venturing into global politics over the past thirty years. With its emphasis on concepts such as path dependency, time, continuity and change, critical junctures, and unintended consequences, Historical Institutionalism proves to be a valuable theoretical tool to make sense of the European Union's development as a foreign policy actor.

As such, this paper argues that the following four elements to a great extent predestined the European Union's development of a foreign policy domain in general, and of becoming involved in its Eastern neighbourhood more specifically: first, the successful economic integration in the first forty years of the European Union's existence; second, the logic of integration through institutionalization driving EU integration since 1952; third, the - at first - informal European Political Cooperation witnessing the emergence of tacit norms and rules of conducting foreign policy coordination; and fourth, the rhetoric commitment to the region of Central and Eastern Europe pre-1989. The economic success of integration in Western Europe - manifested in the establishment of a single European market - has resulted in the area becoming a pool of attraction for third countries. Particularly the closest neighbors, just on the other side of the Iron curtain, having been encouraged for decades to rid themselves of the oppressive Soviet dominance, were prone to turn to Brussels for guidance and assistance on their own path towards a "European future" in the aftermath of the Cold War. To address these calls, the European Union fell back upon a proven recipe: economic association through institutionalization. Yet, the countries of Central and Eastern Europe insisted on their relations with Brussels going beyond economic cooperation only, propelling the Union to design a comprehensive enlargement policy with the goal of not only economic, but also political, transformation of EU candidate countries. In the medium-term, the decision to incorporate Central and Eastern European countries into EU structures drove its subsequent foreign policy development to the wider region in the form of, first, the European Neighbourhood Policy and, later, the Eastern Partnership. All of these EU foreign policy endeavors follow the same institutionalizing logic developed decades earlier. Furthermore, Historical Institutionalism allows us to conceptualize so-called unintended consequences of policy decisions made in an earlier spatio-temporal context. In this paper, the ever-deteriorating EU-Russia relations are problematized as one such unintended consequence of the EU's incremental foreign policy development vis-à-vis Eastern Europe; a region that is considered strategic to Russia's interests.

While this paper confirms the applicability of Historical Institutionalism to the study of the EU's development as a foreign policy actor, it should not be read as depriving the Union as a whole, but also individual member states as its constituent parts, of agency. Although, in line with what Historical Institutionalism predicts, earlier made policy decisions severely limit decision makers' maneuvering space in making any 
subsequent policy change and adjustments, the European Union's transformation into a political actor with a global presence is a sequence of decisions driven by individual member states, who continue to play a dominant role in the ever-expanding, though strictly intergovernmental, domain that is foreign policy.

\section{СПИСОК ЛИТЕРАТУРЫ / REFERENCES}

Averre, Derek. "Competing Rationalities: Russia, the EU and the 'Shared Neighbourhood'." EuropeAsia Studies 61, no. 10 (2009): 1689-1713. https://doi. org/10.1080/09668130903278918.

Bassompierre, Guy de. Changing the Guard in Brussels. New York: Praeger, 1988.

Bechev, Dimitar. “Understanding the Contest between the EU and Russia in their Shared Neighborhood." Problems of Post-Communism 62, no. 6 (2015): 340-349. https://doi.org/10.1080.10758216.201 5.1067751

Capoccia, Giovanni, and R. Daniel Kelemen. "The Study of Critical Junctures: Theory, Narrative and Counterfactuals in Historical Institutionalism." World Politics 59, no. 3: 341-369. https://doi.org/10.1017/ S0043887100020852.

Cadier, David. "Eastern Partnership vs Eurasian Union? The EU-Russia Competition in the Shared Neighbourhood and the Ukraine Crisis." Global Policy 5, no. 1 (2014): 76-85. https://doi.org/10.1111.17585899.12152

Casier, Tom. "The Unintended Consequences of a European Neighbourhood Policy without Russia." The International Spectator 54, no. 1 (2019): 76-88. https:// doi.org/10.1080.03932729.2019.1555224.

Chebankova, Elena. "Russia's Idea of the Multipolar World Order: Origins and Main Dimensions." Post-Soviet Affairs 33, no. 3 (2017): 217-234. https://doi.org/10.1080. 1060586 X.2017.1293394.

Chin, Gregory. "The Emerging Countries and China in the G20: Reshaping Global Economic Governance." Studia Diplomatica 63, no. 2 (2010): 105-123.

Christiansen, Thomas, and Amy Verdun. "Historical Institutionalism in the Study of European Integration." In Oxford Encyclopedia of European Union Politics, edited by Finn Laurse, Oxford: Oxford University Press, 2020.

Comelli, Michele. "The Challenges of the European Neighbourhood Policy." The International Spectator 39, no. 3 (2004): 97-110. https://doi. org/10.1080/03932720408457087.

Cooper, Andrew F. and Daniel Flemes. "Foreign Policy Strategies of Emerging Powers in a Multipolar World: An Introductory Review." Third World Quarterly 34, no. 6 (2013): 943-962. https://doi.org/10.1080.01436 597.2013.802501.

Cronberg, Tarja. "No EU, no Iran Deal: The EU's Choice between Multilateralism and the Transatlantic Link." The Nonproliferation Review 24, no. 3-4: 243-259. https://doi.org/10.1080/10736700.2018.1432321.

Dias, Vanda Amaro. "The EU and Russia: Competing Discourses, Practices and Interests in the Shared Neighbourhood." Perspectives on European Politics and Society 14, no. 2 (2013): 256-271. https://doi.org/10.1080 .15705854.2013.785261.

Delcour, Laure. "Between the Eastern Partnership and Eurasian Integration: Explaining Post-Soviet Countries' Engagement in (Competing) Region-
Building Projects." Problems of Post-Communism 62, no. 6 (2015): 316-327. https://doi.org/10.1080/107582 16.2015 .1057075 .

Delcour, Laure. "Dealing with the Elephant in the Room: The EU, Its 'Eastern Neighbourhood' and Russia." Contemporary Politics 24, no. 1 (2018): 14-29. https://doi. org/10.1080/13569775.2017.1408169.

Flemes, Daniel. "India-Brazil-South Africa (IBSA) in the New Global Order: Interest, Strategies and Values of the Emerging Coalition." International Studies 46, no. 4 (2011): 401-421. https://doi. org/10.1177/002088171004600402.

Gehring, Thomas, Kevin Urbanski, and Sebastian Oberthür. "The European Union as an Inadvertent Great Power: EU Actorness and the Ukraine Crisis." Journal of Common Market Studies 55, no. 4 (2017): 727-743. https://doi.org/10.1111/jcms.12530.

Giandomenico, Jessica. "Path Dependency in EU Enlargement: Macedonia's Candidate Status from a Historical Institutionalist Perspective." European Foreign Affairs Review 14, no. 1 (2009): 89-112.

Ginsberg, Roy H., and Michael E. Smith. "Understanding the European Union as a Global Political Actor: Theory, Practice, and Impact." In Making History: European Integration and Institutional Change at Fifty, edited by Sophie Meunier and Kathleen R. McNamara, 267-281. Oxford: Oxford University Press, 2007.

Juncos, Ana E. "Resilience as the New EU Foreign Policy Paradigm: A Pragmatist Turn?" European Security 26, no. 1 (2017): 1-18. https://doi.org/10.1080.09662839 .2016.1247809.

Kazharski Aliaksei, and Andrey Makarychev. "Suturing the Neighborhood? Russia and the EU in Conflictual Intersubjectivity." Problems of PostCommunism 62, no. 6 (2015): 328-339. https://doi.org/10 .1080.10758216.2015.1057077.

Keukeleire, Stephan, and Tom Delreux. The Foreign Policy of the European Union. Basingstoke: Palgrave Macmillan, 2014.

Laatikainen, Katie Verlin, and Karen E. Smith (eds). The European Union at the United Nations. London: Palgrave Macmillan, 2006.

Lane, David. "Post-Communist States and the European Union." Journal of Communist Studies and Transition Politics 24, no. 4 (2007): 461-477. https://doi. org/10.1080/13523270701674558.

Lukyanov, Fyodor. "Russian Dilemmas in a Multipolar World." Journal of International Affairs 63, no. 2 (2010): 19-32.

Pänke, Julian. "Liberal Empire, Geopolitics and EU Strategy: Norms and Interests in European Foreign Policy Making." Geopolitics 24, no. 1: 100-123. https://doi.org/10.1080/14650045.2018.1528545.

Pollack, Mark A. "Rational Choice and Historical Institutionalism." In European Integration Theory, edited by Antje Wiener, Tanja A. Börzel, and Thomas Risse, 108-127. Oxford: Oxford University Press, 2019. 
Mahoney, James, and Kathleen Thelen. "A Theory of Gradual Institutional Change." In Explaining Institutional Change: Ambiguity, Agency, and Power, edited by James Mahoney and Kathleen Thelen, 1-37. Cambridge: Cambridge University Press, 2010.

Makarychev, Andrey. Russia and the EU in a Multipolar World: Discourses, Identities, Norms. Stuttgart: Ibidem-Verlag, 2014.

Meunier Sophie, and Kathleen R. McNamara, eds. Making History: European Integration and Institutional Change at Fifty. Oxford: Oxford University Press, 2007.

Missiroli, Antonio. "The ENP in Future Perspective." In The European Neighbourhood Policy in Perspective: Context, Implementation and Impact, edited by Richard G. Whitman and Stefan Wolff, 259-270. Basingstoke: Palgrave Macmillan, 2010.

Neuman, Marek. Too Small to Make an Impact? The Czech Republic's Influence on the European Union's Foreign Policy. Frankfurt am Main: Peter Lang, 2015.

Noutcheva, Gergana. "Whose Legitimacy? The EU and Russia in Contest for the Eastern Neighbourhood." Democratization 25, no. 2 (2018): 312-330. https://doi.or g/10.1080.13510347.2017.1363186.

Pierson, Paul. "The Path to European Integration: A Historical Institutional Analysis." Comparative Political Studies 29, no. 2 (1996): 123-163.

Rittberger, Berthold. "Which Institutions for Post-War Europe? Explaining the Institutional Design of Europe's First Community." Journal of European Public Policy 8, no. 5 (2011): 673-708. https://doi. org/10.1080.13501760110083464.

Rosamond, Ben. "The Uniting of Europe and the Foundation of EU Studies: Revisiting the Neofunctionalism of Ernst B. Haas." Journal of European Pubic Policy 12, no. 2 (2005): 237-254. https://doi. org/10.1080.13501760500043928.

Sasse, Gwendolyn. "The European Neighbourhood Policy: Conditionality Revisited for the EU's Eastern Neighbours." Europe-Asia Studies 60, no. 2 (2008): 295-316. https://doi.org//10.1080.09668130701820150.

Sasse, Gwendolyn. "The European Neighbourhood Policy and Conflict Management: A Comparison of Moldova and the Caucasus." Ethnopolitics 8, no. 3-4 (2009): 369-386. https://doi. org/10.1080.17449050903086971.

Saurugger, Sabine. "Sociological Institutionalism and European Integration." In Oxford Encyclopedia of European Union Politics, edited by Finn Laursen. Oxford: Oxford University Press, 2020.
Schmidt, Vivien A. "Discursive Institutionalism: The Explanatory Power of Ideas and Discourse." Annual Review of Political Science 11, no. 11 (2008): 303-326. https://doi.org/10.1146/annurev. polisci.11.060606.135342.

Schneider, Gerald, and Anastasia Ershova. "Rational Choice Institutionalism and European Integration." In Oxford Encyclopedia of European Union Politics, edited by Finn Laursen. Oxford: Oxford University Press, 2020.

Smith, Martin A. "Russia and Multipolarity since the End of the Cold War." East European Politics 29, no. 1 (2013): 36-57. https://doi.org/10.1080/21599165.2013. 764481.

Smith, Karen E. "The Outsiders: The European Neighbourhood Policy." International Affairs 81, no. 4 (2005): 757-773.

Smith, Michael E. "Diplomacy by Decree: The Legalization of EU Foreign Policy." Journal of Common Market Studies 39, no. 1 (2001): 79-104.

Tocci, Nathalie. "Firm in Rhetoric, Compromising in Reality: The EU in the Israeli-Palestinian Conflict." Ethnopolitics 8, no. 3-4 (2009): 387-401. https://doi. org/10.1080.17449050903086989.

Tocci, Nathalie. "Resilience and the role of the European Union in the World." Contemporary Security Studies 41, no. 2 (2020): 176-194. https://doi.org.10.1080 .13523560 .2019 .1640342 .

Tonra, Ben, and Thomas Christiansen, eds. Rethinking European Union Foreign Policy. Manchester: Manchester University Press, 2004.

Trenin, Dmitri. "Russia's Spheres of Interest, not Influence." The Washington Quarterly 32, no. 4 (2009): 3-22. https://doi.org/10.1080.01636600903231089.

Vachudova, Milada Anna. "Historical Institutionalism and the EU's Eastward Enlargement." In Making History: European Integration and Institutional Change at Fifty, edited by Sophie Meunier, and Kathleen R. McNamara, 105-120. Oxford: Oxford University Press, 2007.

Verdun, Amy. "A Historical Institutionalist Explanation of the EU's Response to the Euro Area Financial Crisis." Journal of European Public Policy 22, no. 2 (2015): 219-237. https://doi.org/10.1080.13501763.2014.994023.

Wallace, William. "European Foreign Policy since the Cold War: How Ambitious, How Inhibited?" The British Journal of Politics and International Relations 19, no. 1 (2017): 77-90. https://doi. org/10.1177/1369148116685297.

\section{Author \\ Marek Neuman, \\ Assistant Professor, University of Groningen, Faculty of Arts, Department of International Relations and International Organization, PO Box 716, 9700 AS, Groningen, the Netherlands. \\ e-mail: m.neuman@rug.nl}

\section{Additional information}

Received: April 1, 2021. Revised: April 26, 2021. Accepted: September 20, 2021.

\section{Disclosure statement}

No potential conflict of interest was reported by the author.

\section{For citation}

Neuman, Marek. "Historical Institutionalism and the European Union's post-Cold War Foreign

Policy Development." Journal of International Analytics 12, no. 3 (2021): 72-86.

https://doi.org/10.46272/2587-8476-2021-12-3-72-86 


\title{
Исторический институционализм и эволюция внешней политики Европейского союза после окончания холодной войны
}

\begin{abstract}
АННОТАЦИЯ
В данной статье утверждается, что исторический институционализм - с его акцентом на таких концептах, как зависимость от предшествующего развития, время, непрерывность и изменение, критические моменты и непредвиденные последствия - служит ценным теоретическим инструментом для объяснения того, почему и как Европейский союз трансформировался из исключительно экономического союза в течение первых сорока лет своего существования в направлении политического союза с глобальной внешнеполитической повесткой дня в период после холодной войны. Через анализ эволюции внешней политики ЕС после 1989 г. и рассмотрение политики ЕС в отношении Восточной Европы автор утверждает, что участие Брюсселя в мировой политике уже давно находится в процессе становления. В частности, выделяются четыре элемента, которые определили и продолжают определять внешнеполитический портфель ЕС: во-первых, успешная экономическая интеграция в первые сорок лет существования Европейского союза;

во-вторых, логика интеграции через институционализацию, которая двигала интеграцию

в ЕС с 1952 г.; в-третьих, неформальное европейское политическое сотрудничество, свидетельствующее о появлении негласных норм и правил проведения внешнеполитической координации; и, в-четвертых, риторическая приверженность региону Центральной и Восточной Европы до 1989 г.
\end{abstract}

\section{КЛЮЧЕВЫЕ СЛОВА}

Европейский союз, внешняя политика, исторический институционализм, зависимость от предшествующего развития, непредвиденные последствия, Европейская политика соседства, Восточное партнерство

\author{
Сведения об авторе \\ Марек Нойман, \\ Университет Гронингена, Факультет искусств, \\ кафедра международных отношений и международной организации, \\ 716, 9700 AS, гронинген, Нидерланды. \\ e-mail: m.neuman@rug.nl \\ Дополнительная информация \\ Поступила в редакцию: 1 апреля 2021. \\ Переработана: 26 апреля 2021. \\ Принята к публикации: 20 сентября 2021.

\section{Конфликт интересов} \\ Автор заявляет об отсутствии потенциального конфликта интересов.
}

\section{Цитирование}

Нойман, М. Исторический институционализм и эволюция внешней политики Европейского союза после окончания холодной войны // Международная аналитика. - 2021. - Том 12 (3). - С. 72-86. https://doi.org/10.46272/2587-8476-2021-12-3-72-86 